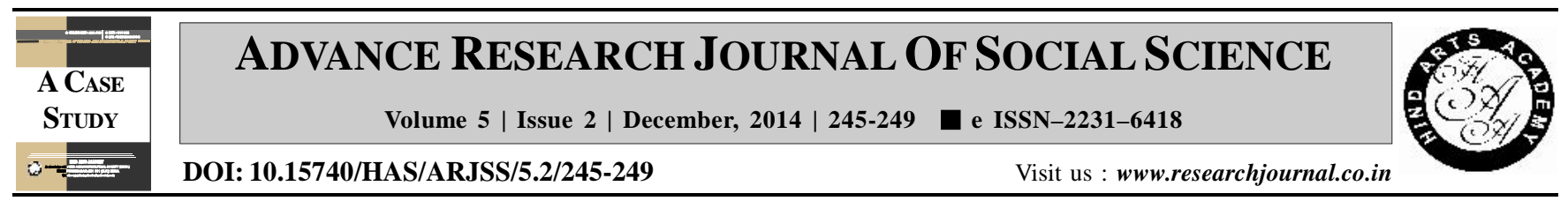

\title{
Women of urban Punjab in hosiery industry
}

K. Shilla*, P. Sandhu, S. Bal and M. Sidhu

Department of Family Resource Management, College of Home Science, Punjab Agricultural University, LUDHIANA(PUNJAB) INDIA

\section{ARTICLE INFO :}

Received : 21.10 .2014

Accepted : 25.11 .2014

\section{KEY WORDS :}

Unorganized sector, Hosiery units, Women workers

\section{HOW TO CITE THIS ARTICLE :}

Shilla, K., Sandhu, P., Bal, S. and Sidhu, M. (2014). Women of urban Punjab in hosiery industry. Adv. Res. J. Soc. Sci., 5 (2) : 245-249.

*Author for correspondence

\begin{abstract}
Women workers in the unorganized sector like hosiery units deserve special emphasis in view of the double burden of work that distinguishes women from men. Hosiery industry is the hub of Ludhiana city, where women work as casual workers to do minor hand operations on manufactured hosiery garments. Present study was conducted to examine the work environment of women workers in hosiery units of Ludhiana city. Results revealed that maximum number $(60.83 \%)$ of respondents was in age category of 35-60 years; married $(71.83 \%)$; belonged to Hindu religion $(57.50 \%)$ and were matriculates $(53.33 \%)$. They lived as nuclear family 88.73 per cent. Monthly income earned by most of them (90.00\%) was from Rs. 1000-5000/-. Most of them $(63.33 \%)$ lived in rented house, but almost all of them $(98.33 \%)$ lived in Pacca house only. Most of them (69) were of normal body type. Almost all (116) the respondents were right handers.
\end{abstract}

